\title{
The soya bean value chain in Tanzania
}

\section{Introduction}

A value chain describes the activities required to move a commodity through the various stages from the first point of production to the last point of consumption. This usually involves (an often complex) combination of physical change, inputs from various producer services, transfer of ownership and delivery. ${ }^{1}$ Commodity value chains are increasingly recognized as providing a solid framework for the analysis of the public and private sector participants within them as well as the overall performance of particular markets. Tanzania's soya bean value chain, from supply and use of inputs, via production and processing to marketing and retailing and on to the consumer is confounded by many technical and institutional impediments. The chain is fragmented, unorganized, disorganized, uncontrolled (in spite, in some links, of being over-regulated) and uncoordinated. ${ }^{2}$ There is an unknown but, in terms of total national smallholder families, small number of households involved in primary production. A very few large farms grow soya on a regular basis but more of this type of production is expected. ${ }^{3-5}$ Brokers or traders operate across most links of the chain. Some processing is done at household level and there is a (growing) number of small and large scale commercial

\author{
Volume 8 Issue 3 - 2018
}

\author{
R Trevor Wilson \\ Bartridge Partners, Bartridge House, Umberleigh, UK
}

Correspondence: $\mathrm{R}$ Trevor Wilson, Bartridge Partners, Bartridge House, Umberleigh, EX37 9AS, UK, Tel +44 1769 560244; Email trevorbart@aol.com

Received: March 16, 2018 | Published: May 04, 2018

processors who produce both human food and animal feed with soya as an ingredient. ${ }^{6}$ Human food containing soya or soya bean meal is sold in some supermarkets and smaller retail outlets. Soya in animal feeds is used by the manufacturer or sold retail to individual livestock farmers mainly in the poultry layer or broiler segment. ${ }^{7}$ The horizontal and vertical linkages of the value chain are generally weak and uncompetitive and in need of support to strengthen them.

Table I Simple listing of supply and service participants in the Soya Bean Value Chain

\begin{tabular}{ll}
\hline Core actors & Service suppliers \\
\hline $\begin{array}{l}\text { Producers (smallholder farmers, farmer groups, large scale } \\
\text { farmers with possible outgrowers) }\end{array}$ & Research Training and Education Institutions \\
Traders and agents & Extension service \\
Processors & Inputs (seed, fertilizer, plant health products) \\
Wholesalers & Transport \\
Retailers (shops, supermarkets) & Financial services \\
\hline Importers (soya meal from India and Zambia) & Associations (producer, trader, processor) Cereal and Mixed Crops Board \\
\hline
\end{tabular}

Table 2 Participants and functions in the Soya Bean Value Chain

\section{Participant Functions}

Most soya beans are grown by traditional smallholders, mostly located in the Southern Highlands with another group around Babati in Manyara Region, who use little technology. Some small scale farmers receive support from NGOs in technology and group

Producers formation. Large scale grower are concentrated in the so-called lhemi Cluster of SAGCOT around Mafinga (some already have "outgrowers" and others have plans to develop an outgrower programme). There are other large scale producers in Arusha and Kilimanjaro Regions.

Traders $\quad$ Primary buyers or brokers and secondary buyer-agents operate throughout the country wherever soya is grown. Trading usually takes place at the point of production. A majority of traders have close links with the processors. Some large scale and numerous small and medium scale processors operate mainly in Dar es Salaam and Arusha with limited presence elsewhere in the country. Processing is for inclusion in human foods as fortifiers. Numerous (as many as 500 with trading licences) small private retailers sell small quantities of feed and feed additives and supplements. Main products are Chick Starter

Processors (and a more expensive version containing a coccidiostat), Layers, Broiler Starter, Broiler Growers and Broiler Finisher: in 2013 all is in the form of mash although some firms have or will shortly have pelleting capacity. There is no regular production of pig compound feeds. Many small producers buy ingredients and mix their own concentrate feed.

Wholesalers Most processors act as their own wholesalers although there is a limited number of independent specialist dealers.

Retailers Processors often act as their own retailers. Supermarkets are the main retail outlets although soya fortified food products are also Retailers occasionally on sale in small urban and rural shops. Retailing of soya beans is usually done by recognized but informal businesses.

Input Little use is made of modern inputs by smallholders. Seeds are available in very limited quantities through Uyole, the Agricultural suppliers Seeds Agency (ASA) and other suppliers. Fertilizer and crop health products are available at agro-dealer shops. MAFC and the municipalities provide limited extension services. Financial services are extremely limited and available only to a favoured few. Public sector research on soya is very limited. Uyole Agricultural Research Institute Mbeya has a single researcher working on soya. It also has responsibilities in training and extension. Some large

Research farmers undertake their own "research", mainly in the form of variety observation plots: one farmer is collaborating with the Centro Internacional de Agricultura Tropical (CIAT, International Centre for Tropical Agriculture) in this kind of trial. 


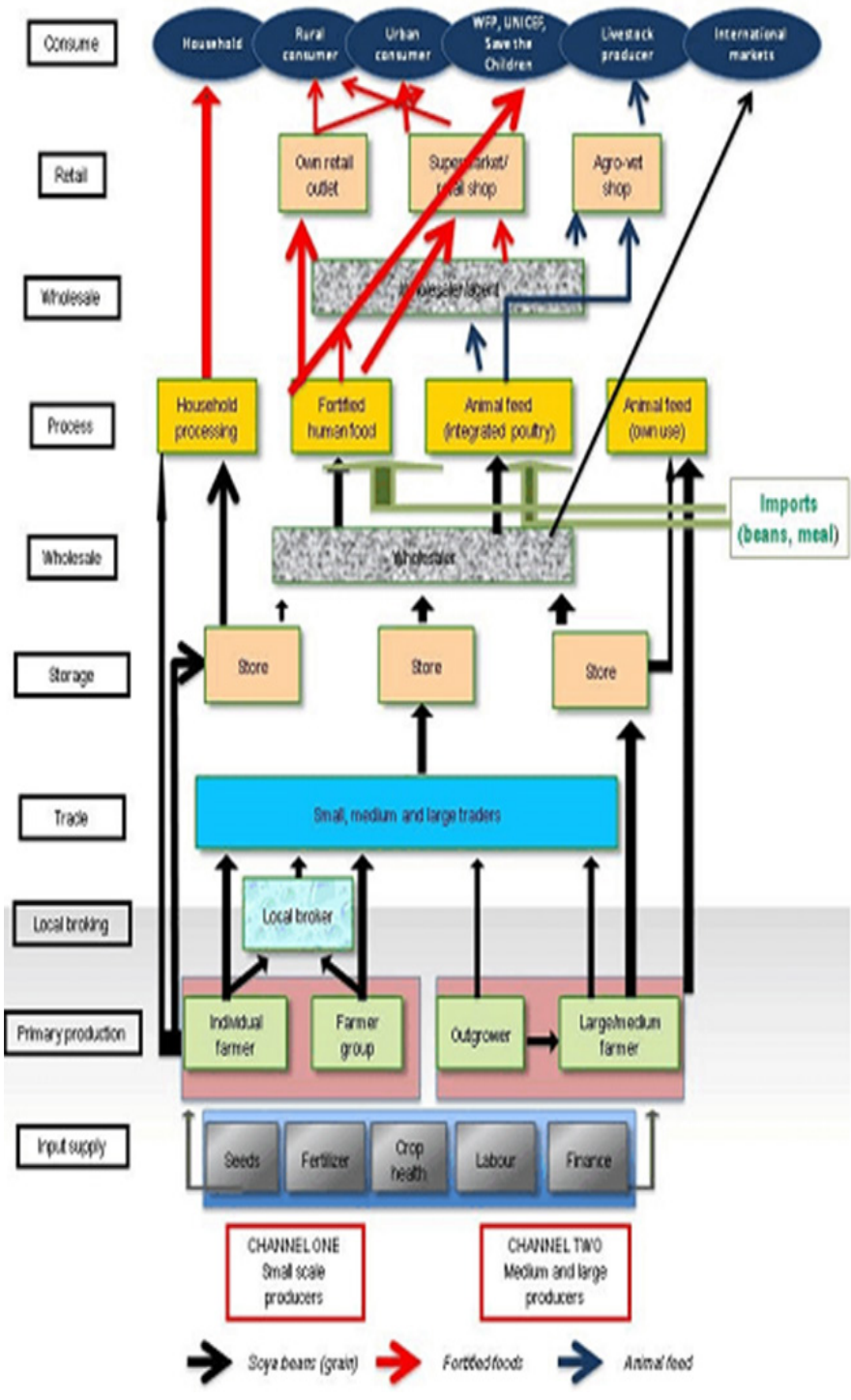

Figure I The Soya Bean Value Chain in Tanzania.

The soya bean value chain includes whole beans and soya bean meal. Both items are produced mainly for the domestic market. Imports are almost all soya bean meal for the livestock feed industry and small amounts of oil for cooking. Processed products are derived after some form of treatment to extract protein (the primary case in Tanzania) or oil. Soya bean meal is the material remaining after solvent extraction or mechanical expelling of oil from the bean and has a protein content of about 50 per cent. The meal is "toasted" (a misnomer because the heat treatment is with moist steam) and then ground in a hammer mill before being incorporated into animal feed. Participants in the chain include primary producers, traders, processors, wholesalers and retailers and consumers. Most participants are rather specialized and their functions relate to one or a very few links in the chain.

\section{The value chain map}

The value chain map (Figure 1) shows that the whole is suspended from the end user. If the link to the rest of the chain were to be broken the whole would be susceptible to collapse. This situation is more or less true for all other links in the chain. Each link takes the product from its immediate predecessor and "processes" it to an output that is used by the next link. Nominally, the value of product increases at each stage until it reaches the consumer. It is possible to provide a succinct list of most of the participants in the chain (Table 1) but pivotal roles are played by the middle links through which all products must pass. Many participants in the chain (Table 2) occupy more than one role. Further up the chain some processors are also wholesalers and retailers and operate in both the domestic and export markets. Primary producers may sell beans directly through a market, to a trader or to a processor or may use a combination of all three outlets. A trader can sell to another trader, directly to a wholesaler or retailer or to a processor or, again, may broaden his option by using a combination of these channels. Processors, especially the smaller enterprises, may buy beans directly from farmers or from traders and sell the products to wholesalers or retailers.

\section{Conclusion}

Every link in the chain relies on goods and services in order to fulfil its role(s). At the various stages, goods and services include land, labour, soya beans and meal, input suppliers for fertilizers and plant health products, transport, energy and finance. Also required are clearly defined and enunciated standards and a regulatory framework under-and applied by-law. Many of these requirements continue to be weak or non-existent in Tanzania.

\section{Funding details}

This paper is an extract from a soya bean study which was one of a series of commodity studies carried out by the Tanzania Southern Highlands Food Systems Programme. These studies were financed by the Food and Agriculture Organization of the United Nations.

\section{Acknowledgements}

Michael Winklmaier, Chief Technical Adviser of the Southern Highlands Food Systems, is thanked for his encouragement and support during the course of the original study. Joan Kimirei, National Consultant to the main project, is thanked for assistance during an extended trip up-country, as is Peter Jimbuku, driver extraordinary and general factotum.

\section{Conflict of interest}

The author declares no conflict of interest.

\section{References}

1. Porter ME, Competitive Advantage: Creating and Sustaining Superior Performance. New York: Simon and Schuster; 1985.

2. R Trevor Wilson. MMA, Soya Value Chain Analysis for SAGCOT (Report prepared as part of the SAGCOT Investment Blueprint). Dar es Salaam. Match Maker Associates Ltd; 2010.

3. URT (United Republic of Tanzania), Status of soybean production and utilization in Tanzania (Final Report January 2006). Dar es Salaam: Ministry of Agriculture, Food Security and Cooperatives; 2006. 30-28 p.

4. URT, National Sample Census of Agriculture 2007/2008 Small Holder Agriculture Volume III: Livestock Sector - National Report. Dar es Salaam: Prime Minister's Office; 2012.

5. URT, National Sample Census of Agriculture 2007/2008. Large Scale Farms Volume IV. Dar es Salaam: Prime Minister's Office; 2012. 
6. Kimenya F. Soyabean processing and utilization in Tanzania. In: Malema BA, et al. editors. Production and sustainable use of soyabean in Tanzania. Soya bean production and utilization in Tanzania. Proceedings of the Second National Soyabean Stakeholders Workshop, 20-22 December 2006, Morogoro, Tanzania; 2006:29-38.

7. Mwasha ES. Soybean in feed formulation in Tanzania: The past, current, and future demand-what should be done. In: Myaka FA, et al. editors. Proceedings of the First National Soybean Stakeholders Workshop, 10-11 November 2005, Morogoro, Tanzania; 2005:39-46. 